Article

\title{
High-Yield Synthesis of Helical Carbon Nanofibers Using Iron Oxide Fine Powder as a Catalyst
}

\section{Yoshiyuki Suda ${ }^{1, *}$, Koji Maruyama ${ }^{1}$, Tetsuo Iida ${ }^{1}$, Hirofumi Takikawa ${ }^{1}$, Hitoshi Ue ${ }^{2}$, Kazuki Shimizu ${ }^{3}$ and Yoshito Umeda ${ }^{4}$}

1 Department of Electrical and Electronic Information Engineering, Toyohashi University of Technology, Toyohashi, Aichi 441-8580, Japan

2 Fuji Research Laboratory, Tokai Carbon Co., Ltd., Oyama, Shizuoka 410-1431, Japan

3 Development Department, Shonan Plastic Manufacturing Co., Ltd., Hiratsuka, Kanagawa 254-0807, Japan

4 Corporate Research Department, Toho Gas Co., Ltd., Nagoya, Aichi 456-8511, Japan

* Author to whom correspondence should be addressed; E-Mail: suda@ee.tut.ac.jp;

Tel.: +81-532-44-6726; Fax: +81-532-44-6757.

Academic Editor: Daniele Gozzi

Received: 15 September 2014 / Accepted: 22 December 2014 / Published: 8 January 2015

\begin{abstract}
Carbon nanocoil (CNC), which is synthesized by a catalytic chemical vapor deposition (CCVD) method, has a coil diameter of 300-900 nm and a length of several tens of $\mu \mathrm{m}$. Although it is very small, CNC is predicted to have a high mechanical strength and hence is expected to have a use in nanodevices such as electromagnetic wave absorbers and field emitters. For nanodevice applications, it is necessary to synthesize CNC in high yield and purity. In this study, we improved the conditions of catalytic layer formation and CCVD. Using optimized CVD conditions, a CNC layer with a thickness of $>40 \mu \mathrm{m}$ was grown from a $\mathrm{SnO}_{2} / \mathrm{Fe}_{2} \mathrm{O}_{3} / \mathrm{SnO}_{2}$ catalyst on a substrate, and its purity increased to $81 \% \pm 2 \%$.
\end{abstract}

Keywords: carbon nanocoil; carbon nanomaterials; chemical vapor deposition; nanodevices; catalyst metals 


\section{Introduction}

Nanotechnology holds potential not only for miniaturization, densification, and increasing device performance but also for changing nanometer-scale physical properties and creating products with novel functions [1]. Therefore, materials for nanotechnology are now intensively researched. Among them, carbon nanomaterials have attracted considerable attention since the discovery of fullerene in 1985 [2]. Carbon nanotubes (CNTs) [3,4] and various types of carbon nanofibers (CNFs) [5] have also drawn increasing attraction.

In 1990, Motojima et al. [6] synthesized carbon microcoil (CMC), which is a regular-shaped helical carbon fiber, via catalytic chemical vapor deposition (CCVD) using a $\mathrm{Ni}$ catalyst-coated graphite substrate and feedstock gases $\left(\mathrm{C}_{2} \mathrm{H}_{2}, \mathrm{H}_{2}, \mathrm{~N}_{2}\right.$, and $\left.\mathrm{C}_{4} \mathrm{H}_{4} \mathrm{~S}\right)$. Motojima et al. [7] suggested that the growth mechanism of CMCs involved carbon segregation from the crystal facets of the catalyst nanoparticles.

After the discovery of $\mathrm{CMC}$, the growth of carbon nanocoil (CNC), which is also a helical fiber and has a coil diameter of several hundreds of nanometers, was reported [8]. CNCs can be grown using Fe-coated indium-tin-oxide (ITO) and Ni-coated $\mathrm{Cu}$ substrates [8-10]. Furthermore, multi-walled CNC (MWCNC) grown by CCVD using an $\mathrm{Fe}(\mathrm{CO})_{5}$-coated substrate and $\mathrm{C}_{5} \mathrm{H}_{5} \mathrm{~N}$ feedstock gas $[11,12]$ has been reported. Like the structure of CNTs, the structure of MWCNC is graphitic.

Figure 1 shows scanning electron microscopy (SEM) images of CNCs; CNC appears spring-like. The diameters of the coil fibers range from 100 to $200 \mathrm{~nm}$, while the outer diameters of the coils range from 300 to $900 \mathrm{~nm}$; the lengths of the coils are micrometer-scale [13-15]. The CNC fibers are composed of amorphous carbon and have structures similar to CMC.

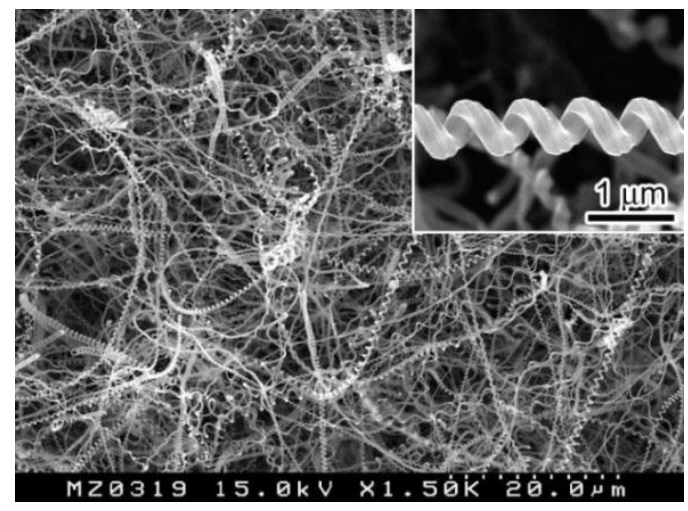

Figure 1. Scanning electron microscopy (SEM) micrograph of carbon nanocoils (CNCs).

The CCVD method is one of the most powerful techniques for synthesis of CNT, CNF, and CNC, although carbon nanomaterials can be synthesized using various methods including arc discharge and laser vaporization [15]. For the growth of CNCs, a combination of two types of catalysts, one with higher carbon segregation ability and another with lower carbon segregation ability, is employed [10,13,16,17]. The model of Motojima can be applied to explain the growth mechanism of CNCs [7]. Very recently, it was reported that a single type of metal catalyst can synthesize CNC by controlling its particle diameter [18]. Metal catalysts can be categorized not only by their carbon segregation abilities, but also by their synergetic effects with other catalysts on carbon segregation; these types of synergistic catalysts are called promoters. Table 1 shows the classification of catalysts. 
Table 1. Classification of catalysts for carbon nanotubes (CNTs) and CNCs growth.

\begin{tabular}{ccc}
\hline Role & Type of catalyst & Catalytic effect \\
\hline \multirow{4}{*}{ Catalyst } & $\mathrm{Ni}[7]$ & \\
& $\mathrm{Fe} \mathrm{[19]}$ & High ability of carbon segregation \\
& $\mathrm{Co}[20], \mathrm{Pd}[21]$ & \\
\hline \multirow{3}{*}{ Promoter } & $\mathrm{Cu}[10], \mathrm{Sn}[19]$ & Low carbon segregation ability \\
& $\mathrm{S}[22]$ & Synergetic effect with catalyst \\
& $\mathrm{In}[23]$ & Keeps the distance between catalyst nanoparticles \\
& $\mathrm{K}[24]$ & Controls the coil diameter \\
\hline
\end{tabular}

Compared to CMCs, CNCs can be applied in electromagnetic absorption materials with shorter wavelengths [25]. They are also used in nanosprings [26-30], electrode materials in fuel cells [31-34], field emitters [35-37], magnetic sensors [38,39], and various industrial fields [40-42].

We have synthesized large quantities of CNCs by employing a drop-coating method that drops an Sn liquid solution mixed with Fe powder on a graphite substrate $[43,44]$. Using this method, the CNC purity on the surface of the deposits reached almost $100 \%$. The CNCs formed a CNC layer with a micrometer-scale thickness. However, there was a carbon layer that did not contain CNCs between the upper and lower CNC layers; this was called the carbon layer. Both the $\mathrm{CNC}$ and carbon layers were grown from a catalyst that was deposited on the substrate. The catalyst is necessary to form solid carbon from gaseous feedstock in the CVD process. It was shown that the carbon layer exists like a "core" between the CNC layers [42]. When we took into account this carbon layer, the CNC purity over the whole deposits grown became 55\%, very low compared to the purity of the CNC layer. The low CNC purity is ascribed to the thickness of the carbon layer. Yokota et al. [45] reported that the thickness of the carbon layer depends on the thickness of the catalyst film on the substrate.

In this study, we attempted to reduce the thickness of the catalyst layer by using a spin-coating method and Fe fine powder to increase the $\mathrm{CNC}$ yield and purity. We used an automatic CVD apparatus with an $\mathrm{Fe}_{2} \mathrm{O}_{3} / \mathrm{SnO}_{2}$-coated substrate and $\mathrm{C}_{2} \mathrm{H}_{2} / \mathrm{N}_{2}$ feedstock gas to synthesize the $\mathrm{CNCs}$, and the produced CNCs were then observed by SEM.

\section{Results and Discussion}

\subsection{Effect of Gas Flow Rate}

We varied the flow rates of $\mathrm{C}_{2} \mathrm{H}_{2}$ feedstock and $\mathrm{N}_{2}$ dilution gases between $100-400 \mathrm{~mL} / \mathrm{min}$ and 1000-1800 $\mathrm{mL} / \mathrm{min}$, respectively. The catalyst structure on the substrate was $\mathrm{SnO}_{2} / \mathrm{Fe}_{2} \mathrm{O}_{3} / \mathrm{SnO}_{2}$, and the $\mathrm{Fe} / \mathrm{Sn}$ molar ratio was 1:2.6. The spin-coating velocity was $1000 \mathrm{rpm}$, and the synthesis time was $10 \mathrm{~min}$. The other CVD conditions were the same as those listed in Table 2. For the experiments where the $\mathrm{N}_{2}$ gas flow rate was varied, the flow rate of $\mathrm{C}_{2} \mathrm{H}_{2}$ gas was fixed at $250 \mathrm{~mL} / \mathrm{min}$. When the $\mathrm{C}_{2} \mathrm{H}_{2}$ gas flow rate was varied, the flow rate of $\mathrm{N}_{2}$ gas was fixed at $1400 \mathrm{~mL} / \mathrm{min}$.

The experimental results for the thicknesses of the $\mathrm{CNC}$ and carbon layers at fixed $\mathrm{N}_{2}$ gas flow rate are shown in Figure 2; the $x$-axis is the flow rate ratio of $\mathrm{N}_{2}$ to $\mathrm{C}_{2} \mathrm{H}_{2}$. A cross-sectional SEM micrograph of the CNC and carbon layers is shown in Figure 3a. When the flow rate of $\mathrm{C}_{2} \mathrm{H}_{2}$ gas was varied, the thicknesses of the $\mathrm{CNC}$ and carbon layers were maximized at a $\mathrm{C}_{2} \mathrm{H}_{2} / \mathrm{N}_{2}$ gas flow ratio of 0.18 and 
decreased for ratios $>0.18$. The difference in thickness between the $\mathrm{CNC}$ and carbon layers was also maximized at the ratio of 0.18 . Similar results were obtained when the flow rate of $\mathrm{N}_{2}$ gas was varied while that of $\mathrm{C}_{2} \mathrm{H}_{2}$ was kept constant. We carefully evaluated a number of SEM micrographs of the CNC layers and concluded that the CNC purity was $\geq 95 \%$ when the $\mathrm{C}_{2} \mathrm{H}_{2} / \mathrm{N}_{2}$ gas flow ratio was within the green-colored range in Figures 2 and $3 \mathrm{c}$. The $\mathrm{C}_{2} \mathrm{H}_{2} / \mathrm{H}_{2}$ ratios outside of the green-colored range resulted in low CNC purities (Figure 3b).

Table 2. Catalytic vapor deposition (CCVD) conditions.

\begin{tabular}{ll}
\hline Catalyst precursor & $\begin{array}{l}\mathrm{Fe}_{2} \mathrm{O}_{3} \text { fine powder (Diameter: } 20 ~ \mathbf{~ m}, \text { Nilaco, Tokyo, Japan) } \\
\mathrm{SnO}_{2} \text { drop-coating solution }(\mathbf{0 . 1 3} \mathrm{M} \text {, Kojundo Chemical } \\
\text { Laboratory, Sakado, Japan) }\end{array}$ \\
\hline Spin-coating velocity & $1000-2500 \mathrm{rpm}$ \\
Catalyst structure & $\mathrm{Fe}_{2} \mathrm{O}_{3} / \mathrm{SnO}_{2}, \mathrm{SnO}_{2} / \mathrm{Fe}_{2} \mathrm{O}_{3} / \mathrm{SnO}_{2}, \mathrm{SnO}_{2} / \mathrm{Fe}_{2} \mathrm{O}_{3}$ \\
Catalyst molar ratio & $\mathrm{Fe}: \mathrm{Sn}=1: 2.6-1: 13$ \\
Feedstock gas (flow rate) & $\mathrm{C}_{2} \mathrm{H}_{2}(100-400 \mathrm{~mL} / \mathrm{min})$ \\
Dilution gas (flow rate) & $\mathrm{N}_{2}(1000-1800 \mathrm{~mL} / \mathrm{min})$ \\
Synthesis temperature & $780{ }^{\circ} \mathrm{C}$ \\
Synthesis time & $0.5-30 \mathrm{~min}$ \\
Annealing temperature & $780{ }^{\circ} \mathrm{C}$ \\
Annealing time & $5 \mathrm{~min}$ \\
\hline
\end{tabular}

These results shown above indicate that when the $\mathrm{C}_{2} \mathrm{H}_{2} / \mathrm{N}_{2}$ gas flow ratio was low, CNC growth was not effective due to the shortage of feedstock gas. On the other hand, when the $\mathrm{C}_{2} \mathrm{H}_{2} / \mathrm{N}_{2}$ gas flow ratio was too high, excess $\mathrm{C}_{2} \mathrm{H}_{2}$ molecules were supplied to the catalyst nanoparticles, decreasing their catalytic activity. In this study, a $\mathrm{C}_{2} \mathrm{H}_{2} / \mathrm{N}_{2}$ flow rate ratio of 0.18 gave the highest $\mathrm{CNC}$ yield and the lowest compositional ratio of the carbon layer to the CNC layer in the deposit [15].

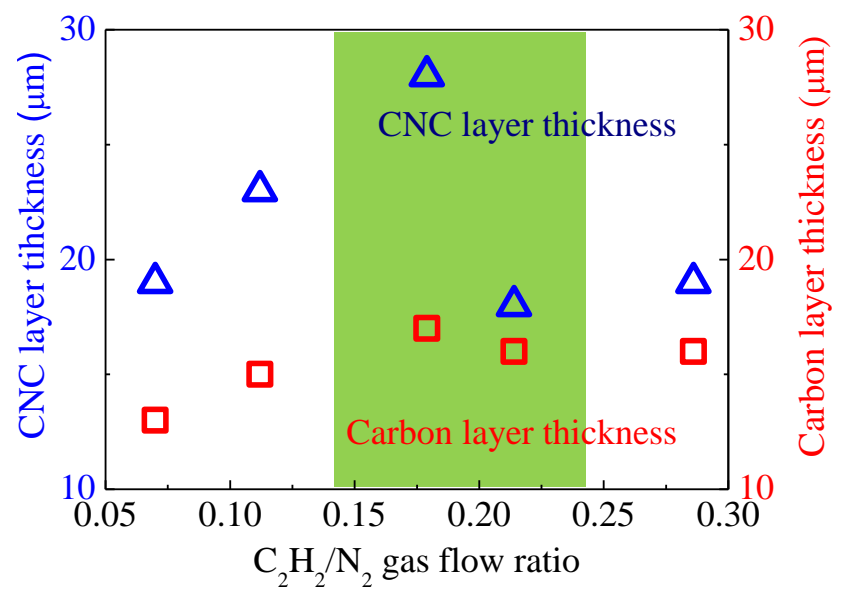

Figure 2. Thicknesses of $\mathrm{CNC}$ and carbon layers $v$ s. $\mathrm{C}_{2} \mathrm{H}_{2} / \mathrm{N}_{2}$ gas flow ratio. The flow rate of $\mathrm{N}_{2}$ gas was fixed at $1400 \mathrm{~mL} / \mathrm{min}$, while that of $\mathrm{C}_{2} \mathrm{H}_{2}$ gas was varied. The green-colored area represents the range for which the $\mathrm{CNC}$ purity in the $\mathrm{CNC}$ layer was $95 \%-100 \%$. 


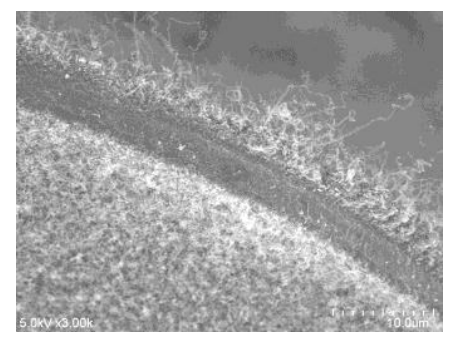

(a)

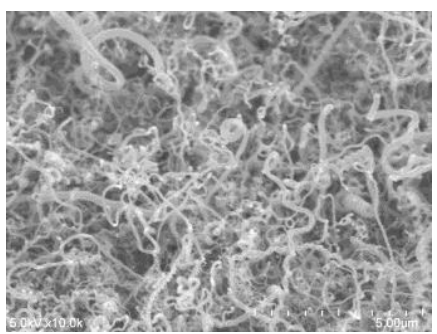

(b)

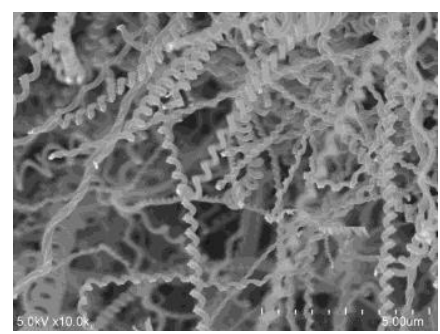

(c)

Figure 3. SEM micrographs of carbon deposits: (a) cross-sectional view of CNC and carbon layers; (b) the surface of a low-purity CNC layer; and (c) the surface of a high-purity CNC layer. In (a), the relatively dark area shows a carbon layer that does not contain CNCs; many CNCs were observed in the other area, which is called the CNC layer.

\subsection{Effect of Spin-Coating Velocity and Synthesis Time}

The effect of spin-coating velocity on catalyst film deposition on the substrate was examined by varying the spin-coating velocity between 1000 and $2500 \mathrm{rpm}$. The catalyst structure on the substrate was $\mathrm{Fe}_{2} \mathrm{O}_{3} / \mathrm{SnO}_{2}$, and the $\mathrm{Fe} / \mathrm{Sn}$ molar ratio was $1: 2.6$. The flow rates of $\mathrm{C}_{2} \mathrm{H}_{2}$ feedstock and $\mathrm{N}_{2}$ dilution gases were $250 \mathrm{~mL} / \mathrm{min}$ and $1400 \mathrm{~mL} / \mathrm{min}$, respectively, and the synthesis time was $10 \mathrm{~min}$. The other CVD conditions are the same as those listed in Table 2.

Figure 4 shows the cross-sectional SEM micrographs of the deposits with spin-coating velocities of 1000 and $1500 \mathrm{rpm}$. The surfaces of CNC layers in Figure 4 are shown in Figure 5, and the correlations between the thicknesses of the CNC and carbon layers and the spin-coat velocity are shown in Figure 6.

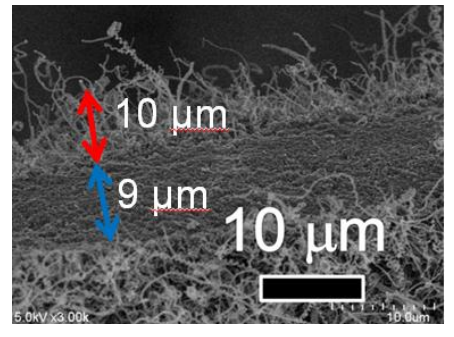

(a)

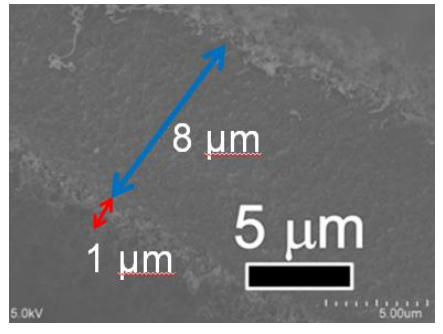

(b)

Figure 4. Cross-sectional SEM micrographs of deposits including CNC and carbon layers obtained at spin-coating velocities of (a) 1000 and (b) $1500 \mathrm{rpm}$. The red and blue arrows represent the thicknesses of $\mathrm{CNC}$ and carbon layers, respectively.

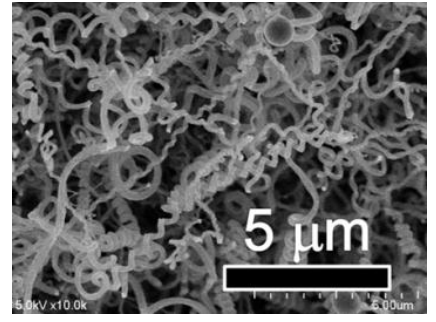

(a)

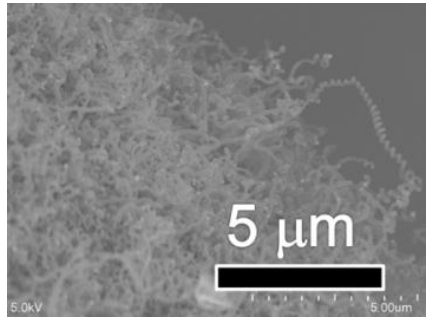

(b)

Figure 5. SEM micrographs of CNC layers obtained at spin-coating velocities of (a) 1000 and (b) $1500 \mathrm{rpm}$. 


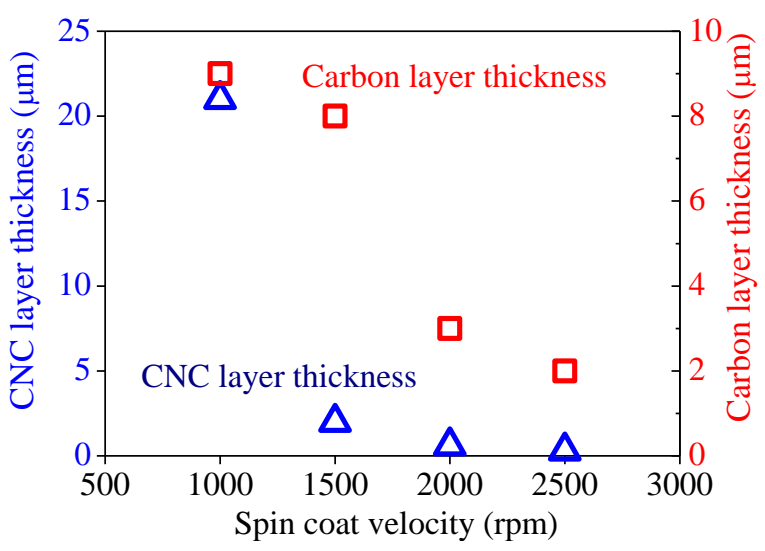

Figure 6. Thicknesses of $\mathrm{CNC}$ and carbon layers $v s$. spin-coat velocity. The synthesis time was $10 \mathrm{~min}$.

The carbon layer thickness decreased with increasing spin-coating velocity because the catalyst film thinned with increasing spin-coating velocity. As the velocity was increased from 1000 to $2500 \mathrm{rpm}$, the film thickness was reduced because some of the liquid solution of $\mathrm{Fe}_{2} \mathrm{O}_{3}$ and $\mathrm{SnO}_{2}$ was blown from the substrate, decreasing the amount of liquid coated on the substrate. When the spin-coating velocity was $1000 \mathrm{rpm}$, the CNC layer was formed; however, the CNC layer was hardly formed at a spin-coating velocity of $1500 \mathrm{rpm}$ and higher. This might result from the inability to build up a stable basement for CNC growth. CNCs were reported to grow preferentially from a catalyst fixed on the dimples of a substrate surface [46]. In the described experiment, the carbon layer acted as a stable basement for CNC growth. If the thickness of the carbon layer became thin, $\mathrm{CNC}$ growth became more difficult. As a result, the optimal spin-coating velocity was $1000 \mathrm{rpm}$; this velocity resulted in the highest CNC purity, although the thickness of the carbon layer was also the highest at this velocity.

We then obtained the effect of the synthesis time by testing times between $30 \mathrm{~s}$ and $30 \mathrm{~min}$ (Figure 7).

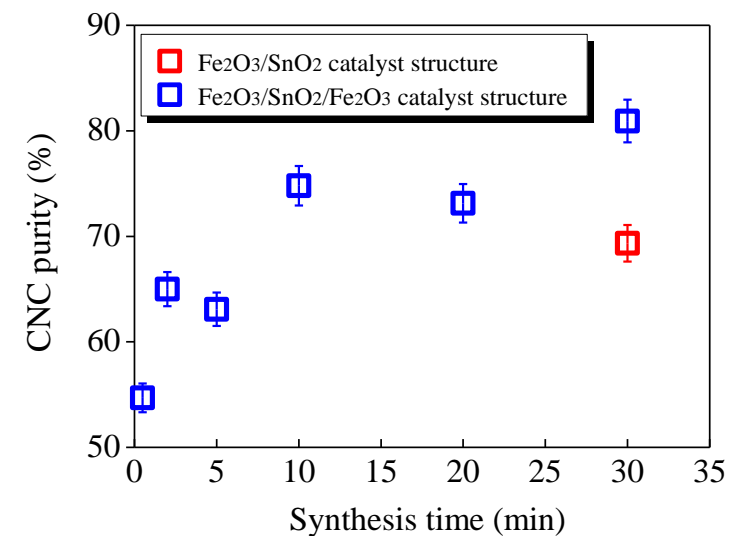

Figure 7. CNC purity vs. synthesis time at spin-coating velocity of $1000 \mathrm{rpm}$.

As synthesis time increased from $30 \mathrm{~s}$ to $10 \mathrm{~min}$, the CNC purity increased constantly. However, the CNC purity remained almost constant at $75 \%$ for synthesis times between $10 \mathrm{~min}$ and $30 \mathrm{~min}$, indicating saturation tendency. 


\subsection{Effect of Catalyst Structure}

The influence of catalyst structure on carbon deposition was examined by testing catalyst structures of $\mathrm{Fe}_{2} \mathrm{O}_{3} / \mathrm{SnO}_{2}, \mathrm{SnO}_{2} / \mathrm{Fe}_{2} \mathrm{O}_{3} / \mathrm{SnO}_{2}$, and $\mathrm{SnO}_{2} / \mathrm{Fe}_{2} \mathrm{O}_{3}$ with a spin-coating velocity of $1000 \mathrm{rpm}$. The $\mathrm{Fe} / \mathrm{Sn}$ molar ratio was 1:2.6, and the flow rates of $\mathrm{C}_{2} \mathrm{H}_{2}$ feedstock and $\mathrm{N}_{2}$ dilution gases were $250 \mathrm{~mL} / \mathrm{min}$ and $1400 \mathrm{~mL} / \mathrm{min}$, respectively. The synthesis time was $30 \mathrm{~min}$. The other CVD conditions are the same as those listed in Table 2.

Figure 8 shows cross-sectional SEM micrographs of the carbon deposits including CNC and carbon layers grown from the three types of catalyst structures. The surfaces of the CNC layers are shown in Figure 9.

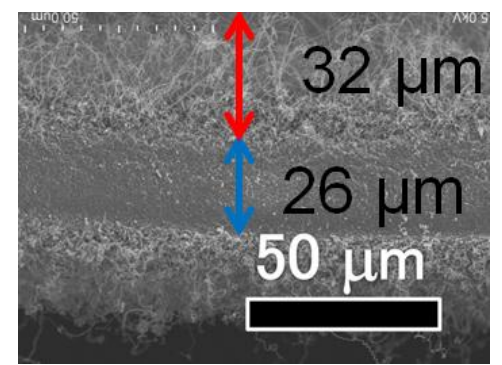

(a)

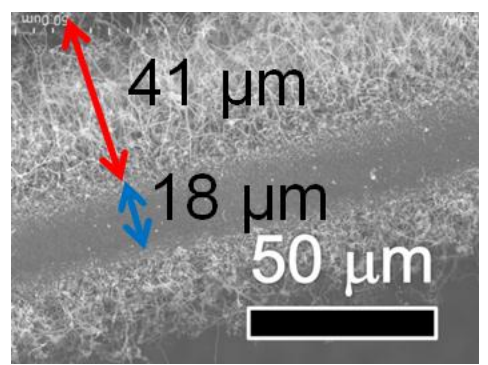

(b)

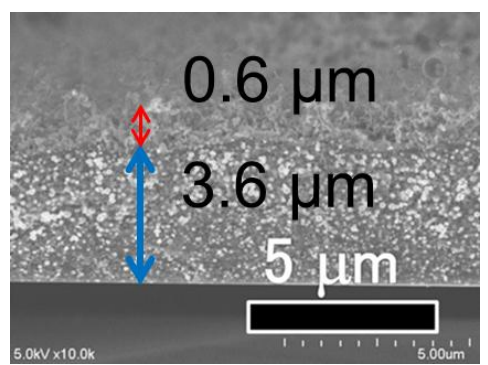

(c)

Figure 8. Cross-sectional SEM micrographs of carbon deposits grown with different catalyst structures: (a) $\mathrm{Fe}_{2} \mathrm{O}_{3} / \mathrm{SnO}_{2}$; (b) $\mathrm{SnO}_{2} / \mathrm{Fe}_{2} \mathrm{O}_{3} / \mathrm{SnO}_{2}$; and (c) $\mathrm{SnO}_{2} / \mathrm{Fe}_{2} \mathrm{O}_{3}$. The red and blue arrows represent the thicknesses of the $\mathrm{CNC}$ and carbon layers, respectively.

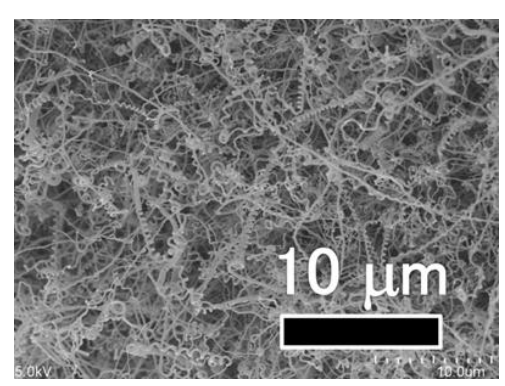

(a)

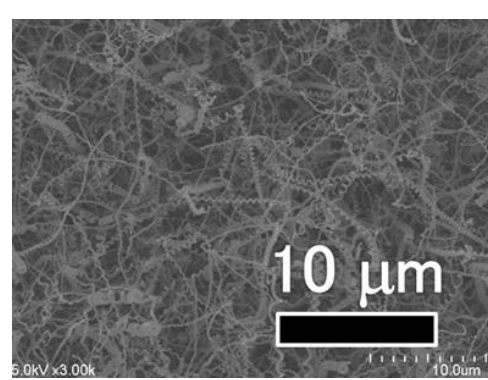

(b)

Figure 9. SEM micrographs of the surfaces of CNC layers grown from different catalyst structures: (a) $\mathrm{Fe}_{2} \mathrm{O}_{3} / \mathrm{SnO}_{2}$ and (b) $\mathrm{SnO}_{2} / \mathrm{Fe}_{2} \mathrm{O}_{3} / \mathrm{SnO}_{2}$. No CNCs were observed on the $\mathrm{SnO}_{2} / \mathrm{Fe}_{2} \mathrm{O}_{3}$ catalyst structure.

As shown in Figure 8, CNC layers were formed on the (a) $\mathrm{Fe}_{2} \mathrm{O}_{3} / \mathrm{SnO}_{2}$; and (b) $\mathrm{SnO}_{2} / \mathrm{Fe}_{2} \mathrm{O}_{3} / \mathrm{SnO}_{2}$ catalyst structures; the $\mathrm{CNC}$ purities on their surfaces ranged from $95 \%$ to $100 \%$. The CNC purities were evaluated by Equation (1) to be $69 \% \pm 2 \%$ and $81 \% \pm 2 \%$ for the $\mathrm{Fe}_{2} \mathrm{O}_{3} / \mathrm{SnO}_{2}$ and $\mathrm{SnO}_{2} / \mathrm{Fe}_{2} \mathrm{O}_{3} / \mathrm{SnO}_{2}$ catalyst structures, respectively. The difference in the CNC purity is attributed to the different growth models of the $\mathrm{Fe}_{2} \mathrm{O}_{3} / \mathrm{SnO}_{2}$ and $\mathrm{SnO}_{2} / \mathrm{Fe}_{2} \mathrm{O}_{3} / \mathrm{SnO}_{2}$ catalyst structures (Figure 10). 


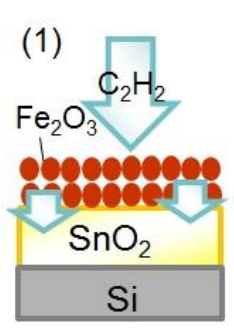

(2)

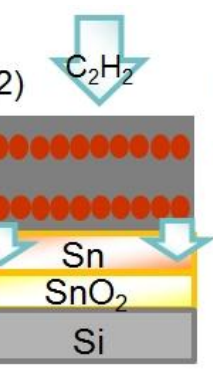

(3)

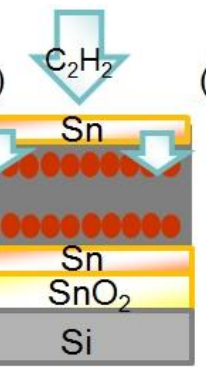

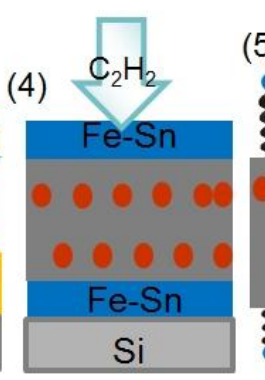

(5)

(a)

(1)

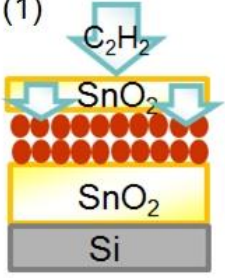

(2)

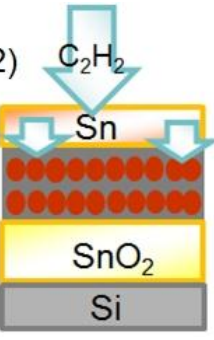

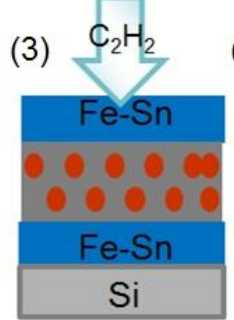

(3)

(b)

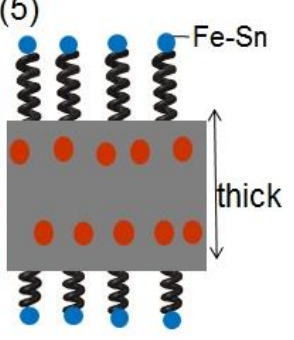


In both of the above models, $\mathrm{C}_{2} \mathrm{H}_{2}$ diffusion in the catalyst thin film is an important process for the growth of the CNC layer. This implies a difference in thickness between the upper and lower CNC layers; the upper layer always became thicker than the lower one, which is located on the other side of the feedstock supply. CNCs were hardly grown on the $\mathrm{SnO}_{2} / \mathrm{Fe}_{2} \mathrm{O}_{3}$ catalyst structure; short and irregularly-shaped carbon fibers were grown instead. This is explained by the limited amount of $\mathrm{C}_{2} \mathrm{H}_{2}$ supplied to $\mathrm{Fe}_{2} \mathrm{O}_{3}$ due to the thick $\mathrm{SnO}_{2}$ layer. Since the carbon segregation ability of Fe is significantly higher that of $\mathrm{Sn}$, carbon growth hardly occurred on $\mathrm{SnO}_{2} / \mathrm{Fe}_{2} \mathrm{O}_{3}$. From the above experimental results, we conclude that the $\mathrm{SnO}_{2} / \mathrm{Fe}_{2} \mathrm{O}_{3} / \mathrm{SnO}_{2}$ catalyst structure was most suitable to grow CNC in high yield and purity.

\section{Experimental Section}

\subsection{Evaluation Method}

In this study, we evaluated the purity of CNCs over the entire deposit. As illustrated in Figure 11, the carbon deposit is sheet-like in shape, and CNCs were grown on both sides of the carbon layer.

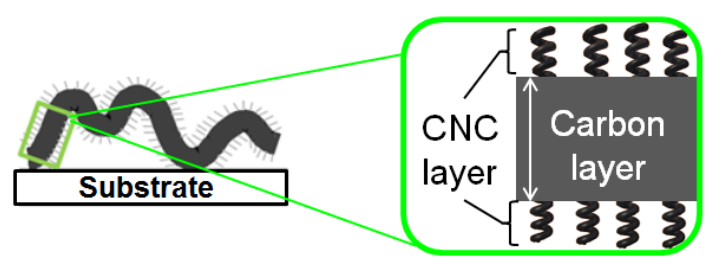

Figure 11. Illustration of the carbon deposit.

The CNC purity was defined by Equation (1):

$$
\text { CNC purity }=\frac{\text { Thickness of CNC layer }}{\text { Thicknesses of CNC and carbon layers }} \times 100(\%)
$$

We assumed the CNC purities in the CNC and the carbon layers to be $100 \%$ and $0 \%$, respectively. This is consistent with the SEM observations of the deposits. The thickness of the CNC layer was obtained as the summation of the upper and lower layers. We examined the CVD conditions and catalyst formation methods in order to maximize the CNC yield and purity.

\subsection{Catalyst Formation}

We used a drop-coating method to deposit catalyst films on substrates, as reported in our previous study $[44,45]$. Although this method is convenient, the catalyst films tended to be thick under our experimental conditions. Thus, in this study, we instead employed a spin-coating method and also attempted to reduce the catalyst film thickness by replacing Fe powder (diameter: 1 and 3-5 $\mu \mathrm{m}$ ) with a finer Fe power (diameter: $20 \mathrm{~nm}$ ). Si was used as a substrate, and liquid solutions of $\mathrm{Fe}_{2} \mathrm{O}_{3}(0.1 \mathrm{M})$ and $\mathrm{SnO}_{2}(0.13 \mathrm{M})$ were used as a catalyst precursor. The spin-coating velocity was varied between 1000 and $2500 \mathrm{rpm}$, and the $\mathrm{Fe}_{2} \mathrm{O}_{3}$ and $\mathrm{SnO}_{2}$ liquids were spin-coated separately on the substrate. After one catalyst film was formed on the substrate, the substrate was dried at $80{ }^{\circ} \mathrm{C}$ for $5 \mathrm{~min}$ to avoid mixing the catalysts during the deposition of multi-layered catalyst thin films. 
We investigated the most suitable catalyst structure for CNC growth and the reduction of carbon layer thickness by SEM observation of three types of catalyst structures: (a) $\mathrm{Fe}_{2} \mathrm{O}_{3} / \mathrm{SnO}_{2}$; (b) $\mathrm{SnO}_{2} / \mathrm{Fe}_{2} \mathrm{O}_{3}$; and (c) $\mathrm{SnO}_{2} / \mathrm{Fe}_{2} \mathrm{O}_{3} / \mathrm{SnO}_{2}$ (Figure 12).

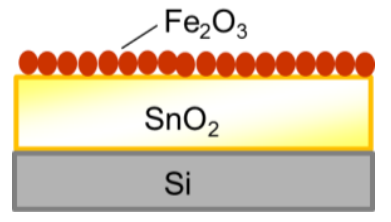

(a)

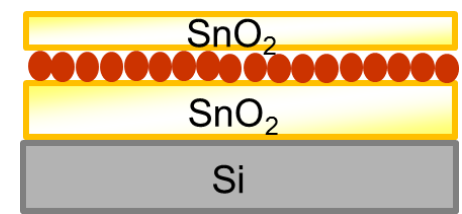

(b)

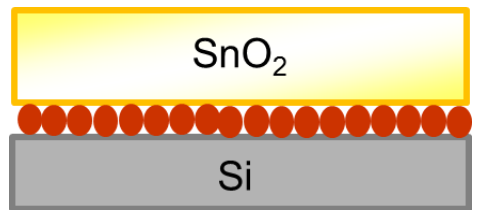

(c)

Figure 12. Catalyst structures formed in this study: (a) $\mathrm{Fe}_{2} \mathrm{O}_{3} / \mathrm{SnO}_{2}$; (b) $\mathrm{SnO}_{2} / \mathrm{Fe}_{2} \mathrm{O}_{3} / \mathrm{SnO}_{2}$; and (c) $\mathrm{SnO}_{2} / \mathrm{Fe}_{2} \mathrm{O}_{3}$ structures.

\subsection{CVD Conditions}

The CVD conditions in this study are listed in Table 2. Figure 13 shows a schematic illustration of the automatic CVD apparatus developed in our laboratory. The details of this apparatus are described elsewhere $[47,48]$.

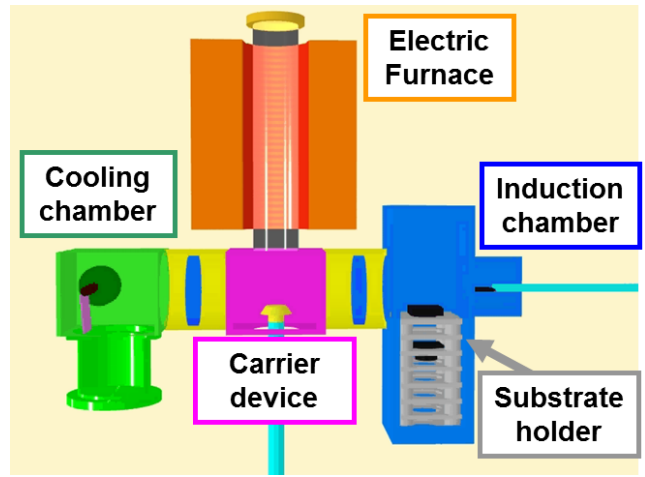

Figure 13. Schematic illustration of the automatic catalytic vapor deposition (CVD) apparatus.

\section{Conclusions}

CNCs have applications in field electron emitters, magnetic wave absorption materials, and nanosprings. However, CNC purity is still low in the carbon deposits as a whole, and improving the CNC purity is necessary for its industrial use. In this study, we attempted to reduce the compositional ratio of the carbon layer, which does not contain CNCs, to the CNC layer and performed CVD experiments.

We varied the flow rates of the feedstock and dilution gases and investigated the CVD conditions to obtain thick and high-purity CNC layers. In a previous study, we used a drop-coating method to deposit catalyst thin films; this resulted in a thick catalyst film and, as a consequence, a thick carbon layer. In this study, we used a spin-coating method to reduce the catalyst film thickness. We changed the diameter of the catalytic Fe powder using in catalyst film deposition from 1 or $3-5 \mu \mathrm{m}$ to $20 \mathrm{~nm}$ to reduce the catalyst film thickness. In the optimization of CVD conditions, the spin-coating velocity and catalyst structure were varied. The identified optimal conditions allowed the formation of a thinner carbon layer and a thicker CNC layer, resulting in a high CNC purity. The CNC purity was improved from 55\% (the highest in our previous studies) to $81 \% \pm 2 \%$ in this study. 


\section{Acknowledgments}

This work was partly supported by the EIIRIS Project from Toyohashi University of Technology (TUT), JSPS KAKENHI Grant Numbers 24360108 and 25630110.

\section{Author Contributions}

Yoshiyuki Suda examined the experimental data and the mechanism of CNC growth in high yield and purity. Koji Maruyama and Tetsuo Iida performed CVD experiments, evaluated CNC growth, and proposed a CNC growth model. Hirofumi Takikawa, Hitoshi Ue, Kazuki Shimizu, and Yoshito Umeda discussed the experimental data.

\section{Conflicts of Interest}

The authors declare no conflict of interest.

\section{References}

1. Sugioka, Y.; Yokota, M.; Pude, T.; Suda, Y.; Takikawa, H.; Tanoue, H.; Ue, H.; Umeda, Y.; Shimizu, K. Effect of filament discharge on upright of carbon nanotwists tightly-adhered to substrate. Jpn. J. Appl. Phys. 2011, 50, doi:10.1143/JJAP.50.08JF08.

2. Kroto, H.W.; Health, J.R.; O’Brien, S.C.; Curl, R.F.; Smally, R.E. C60: Buckminsterfulleren. Nature 1985, 318, 162-163.

3. Iijima, S. Helical microtubules of graphitic carbon. Nature 1991, 354, 56-58.

4. Ihara, S.; Itoh, S. Helically coiled and toroidal cage forms of graphitic carbon. Carbon 1995, 33, 931-939.

5. Nishimura, K.; Kim, Y.A.; Matsushita, T.; Hayashi, T.; Endo, M. Structural characterization of boron-doped submicron vapor-grown carbon fibers and their anode performance. J. Mater. Res. 2000, 15, 1303-1313.

6. Motojima, S.; Kawaguchi, M.; Nozaki, K.; Iwanaga, H. Growth of regularly coiled carbon filaments by $\mathrm{Ni}$ catalyzed pyrolysis of acetylene, and their morphology and extension characteristics. Appl. Phys. Lett. 1990, 56, 321-323.

7. Motojima, S.; Chen, Q. Three-dimensional growth mechanism of cosmo-mimetic carbon microcoils obtained by chemical vapor deposition. J. Appl. Phys. 1999, 85, 3919-3921.

8. Zhang, M.; Nakayama, Y.; Pan, L. Synthesis of carbon tubule nanocoils in high yield using iron-coated indium tin oxide as catalyst. Jpn. J. Appl. Phys. 2000, 39, 1242-1244.

9. Pan, L.; Hayashida, T.; Harada, A.; Nakayama, Y. Effects of iron and indium tin oxide on the growth of carbon tubule nanocoils. Phys. B 2002, 323, 350-351.

10. Katsumata, T.; Fujimura, Y.; Nagayama, M.; Tabata, H.; Takikawa, H.; Hibi, Y.; Sakakibara, T.; Itoh, S. Synthesis of twisted carbon nanofiber by catalytic CVD method. Trans. Mater. Res. Soc. Jpn. 2004, 29, 501-504.

11. Lu, M.; Liu, W.M.; Guo, X.Y.; Li, H.L. Coiled carbon nanotubes growth via reduced-pressure catalytic chemical vapor deposition. Carbon 2004, 42, 805-811.

12. Bajpai, V.; Dai, L.; Ohashi, T. Large-scale synthesis of perpendicularly aligned helical carbon nanotubes. J. Am. Chem. Soc. 2004, 126, 5070-5071. 
13. Takikawa, H.; Yatsuki, M.; Miyano, R.; Nagayama, M.; Sakakibara, T.; Itoh, S.; Ando, Y. Amorphous carbon fibrilliform nanomaterials prepared by chemical vapor deposition. Jpn. J. Appl. Phys. 2000, 39, 5177-5179.

14. Mcllroy, D.N.; Zhang, D.; Kranov, Y.; Norton, M.G. Nanosprings. Appl. Phys. Lett. 2001, 79, 1540-1542.

15. Suda, Y.; Takikawa, H.; Tanoue, H. Syntheses and Electronic Applications of Helical Carbon Nanofibers. In Carbon Nanotubes/Book 2; INTECH: Rijeka, Croatia, 2011; pp. 37-70.

16. Yang, S.; Chen, X.; Kikuchi, N.; Motojima, S. Catalytic effects of various metal carbides and Ti compounds for the growth of carbon nanocoils. Mater. Sci. 2008, 62, 1462-1465.

17. Yokota, M.; Suda, Y.; Takikawa, H.; Ue, H.; Shimizu, K.; Umeda, Y. Structural analysis of multi-walled carbon nanocoils synthesized with Fe-Sn catalyst supported on zeolite. J. Nanosci. Nanotechnol. 2011, 11, 2344-2348.

18. Wang, G.; Ran, G.; Wan, G.; Yang, P.; Gao, Z.; Lin, S.; Fu, C.; Qin, Y. Size-Selective Catalytic Growth of Nearly 100\% Pure Carbon Nanocoils with Copper Nanoparticles Produced by Atomic Layer Deposition. ACS Nano 2014, 8, 5330-5338.

19. Hirahara, K.; Nakayama, Y. The effect of a tin oxide buffer layer for the high yield synthesis of carbon nanocoils. Carbon 2013, 56, 264-270.

20. Sun, L.F.; Mao, J.M.; Pan, Z.W.; Chang, B.H.; Zhou, W.Y.; Wang, G.; Qian, L.X.; Xie, S.S. Growth of straight nanotubes with a cobalt-nickel catalyst by chemical vapor deposition. Appl. Phys. Lett. 1999, 74, 644-646.

21. Nitze, F.; Abou-Hamad, E.; Wagberg, T. Carbon nanotubes and helical carbon nanofibers grown by chemical vapour deposition on C60 fullerene supported Pd nanoparticles. Carbon 2011, 49, 1101-1107.

22. Wei, J.; Zhu, H.; Jia, Y.; Shu, Q.; Li, C.; Wang, K.; Wei, B.; Zhu, Y.; Wang, Z.; Luo, J.; et al. The effect of sulfur on the number of layers in a carbon nanotube. Carbon 2007, 45, 2152-2158.

23. Wang, W.; Yang, K.; Gaillard, J.; Bandaru, P.R.; Rao, A.M. Rational synthesis of helically coiled carbon nanowires and nanotubes through the use of tin and indium catalysts. Adv. Mater. 2008, 20, $179-182$.

24. Tsou, T.Y.; Lee, C.Y.; Chiu, H.T. K and Au bicatalyst assisted growth of carbon nanocoils from acetylene: effect of deposition parameters on field emission properties. ACS Appl. Mater. Interfaces 2012, 4, 6505-6511.

25. Eguchi, U.; Takikawa, H.; Suda, Y. Electromagnetic wave absorption characteristics of multi-walled carbon nano-coils. Jpn. J. Appl. Phys. 2014, 53, doi:10.7567/JJAP.53.045102.

26. Wiliiams, K.L.; Köhler, J.; Boman, M. Fabrication and mechanical characterization of LCVD-deposited carbon micro-springs. Sens. Actuators A 2006, 130-131, 358-364.

27. Feng, C.; Liew, K.M. Structural stability of carbon nanosprings. Carbon 2011, 49, 4688-4694.

28. Yonemura, T.; Suda, Y.; Tanoue, H.; Takikawa, H.; Ue, H.; Shimizu, K.; Umeda, Y. Torsion fracture of carbon nanocoils. J. Appl. Phys. 2012, 112, doi:10.1063/1.4758921.

29. Lim, S.L.; Suda, Y.; Takimoto, K.; Ishii, Y.; Tanoue, H.; Takikawa, H.; Ue, H.; Shimizu, K.; Umeda, Y. Optimization of chemical vapor deposition for reducing the fiber diameter and number of graphene layers in multi-walled carbon nanocoils. Jpn. J. Appl. Phys. 2013, 52, doi:10.7567/JJAP.52.11NL04.

30. Yonemura, T.; Suda, Y.; Shima, H.; Tanoue, H.; Takikawa, H.; Ue, H.; Shimizu, K.; Umeda, Y. Real-time deformation of carbon nanocoils under axial loading. Carbon 2015, 83, 183-187. 
31. Sevilla, M.; Sanchis, C.; Valdes-Solis, T.; Morallon, E.; Fuertes, A.B. Highly dispersed platinum nanoparticles on carbon nanocoils and their electrocatalytic performance for fuel cell reactions. Electrochim. Acta 2009, 54, 2234-2238.

32. Lim, S.L.; Takimoto, K.; Ishii, Y.; Suda, Y.; Tanoue, H.; Takikawa, H.; Ue, H.; Shimizu, K.; Umeda, Y. Improvement of growth yield of multi-walled carbon nanocoils by mesoporous materials and Sn amount. Trans. MRS Jpn. 2011, 36, 469-473.

33. Suda, Y.; Ozaki, M.; Tanoue, H.; Takikawa, H.; Ue, H.; Shimizu, K.; Muramoto, H. Supporting PtRu catalysts on various types of carbon nanomaterials for fuel cell applications. J. Phys. 2013, 433, doi:10.1088/1742-6596/433/1/012008.

34. Suda, Y.; Kaida, S.; Ozaki, M.; Shimizu, Y.; Okabe, Y.; Tanoue, H.; Takikawa, H.; Ue, H.; Shimizu, K. Use of carbon nanocoil as a catalyst support in direct methanol fuel cell. AIP Conf. Proc. 2014, 1585, 77-88.

35. Pan, L.; Konishi, Y.; Tanaka, H.; Sueoka, O.; Nosaka, T.; Nakayama, Y. Effect of morphology on field emission properties of carbon nanocoils and carbon nanotubes. Jpn. J. Appl. Phys. 2005, 44, 1652-1654.

36. Hokushin, S.; Pan, L.; Konishi, Y.; Tanaka, H.; Nakayama, Y. Field emission properties and structural changes of a stand-alone carbon nanocoil. Jpn. J. Appl. Phys. 2007, 46, 565-567.

37. Hosokawa, Y.; Shinohara, Y.; Yokota, M.; Shiki, H.; Suda, Y.; Oke, S.; Takikawa, H.; Ina, T.; Morioki, M.; Fujimura, Y.; et al. Filament discharge enhances field emission properties by making twisted carbon nanofibres stand up. J. Phys. D 2008, 41, doi:10.1088/0022-3727/41/20/205418.

38. Fujii, M.; Matsui, M.; Motojima, S.; Hishikawa, Y. Magnetoresistance in carbon micro-coils annealed at various temperatures. J. Cryst. Growth 2002, 237-239, 1937-1941.

39. Yamamoto, K.; Hirayama, T.; Kusunoki, M.; Yang, S.; Motojima, S. Electron holographic observation of micro-magnetic fields current-generated from single carbon coil. Ultramicroscopy 2006, 106, 314-319.

40. Katsuno, T.; Chen, X.; Yang, S.; Motojima, S.; Homma, M.; Maeno, T.; Konyo, M. Observation and analysis of percolation behavior in carbon microcoils/silicone-rubber composite sheets. Appl. Phys. Lett. 2006, 88, doi:10.1063/1.2206701.

41. Fujiyama, Y.; Tomokane, R.; Tanaka, K.; Akita, S.; Higashi, Y.; Pan, L.; Nosaka, T.; Nakayama, Y. Alignment of carbon nanocoils in polymer matrix using dielectrophoresis. Jpn. J. Appl. Phys. 2008, 47, 1991-1993.

42. Maruyama, K.; Suda, Y.; Tanoue, H.; Takikawa, H.; Ue, H.; Shimizu, K.; Umeda, Y. Improved mechanical properties of bucky paper achieved via the addition of carbon nanocoils. AIP Conf. Proc. 2014, 1585, 89-96.

43. Xu, G.; Chen, B.; Shiki, H.; Katsumata, T.; Takikawa, H.; Sakakibara, T.; Itoh, S.; Ina, T. Parametric study on growth of carbon nanocoil by catalytic chemical vapor deposition. Jpn. J. Appl. Phys. 2005, 44, 1569-1576.

44. Suda, Y.; Ishii, Y.; Miki, T.; Maruyama, K.; Tanoue, H.; Takikawa, H.; Ue, H.; Shimizu, K.; Umeda, Y. Improvement of carbon nanocoil purity achieved by supplying catalyst molecules from the vapor phase in chemical vapor deposition. J. Mater. Res. 2014, 29, 2179-2187. 
45. Yokota, M.; Shinohara, Y.; Kawabata, T.; Takimoto, K.; Suda, Y.; Oke, S.; Takikawa, H.; Fujimura, Y.; Yamaura, T.; Itoh, S.; et al. Splitting and flattening of helical carbon nanofibers by acid treatment. J. Nanosci. Nanotechnol. 2010, 10, 3910-3914.

46. Li, D.; Pan, L. Necessity of base fixation for helical growth of carbon nanocoils. J. Mater. Res. 2012, 27, 431-439.

47. Hosokawa, Y.; Shiki, H.; Shinohara, Y.; Yokota, M.; Takikawa, H.; Ina, T.; Okada, F.; Fujimura, Y.; Yamaura, T.; Itoh, S.; et al. Preparation of powdery carbon nanotwist and application to printed field emitter. Res. Lett. Mater. Sci. 2007, 2007, doi:10.1155/2007/59167.

48. Sugioka, Y.; Suda, Y.; Tanoue, H.; Takikawa, H.; Ue, H.; Shimizu, K.; Umeda, Y. Effects of dielectric barrier discharge treatment conditions on the uprightness of carbon nanofibers. IEEE Trans. Plasma Sci. 2012, 40, 1794-1800.

(C) 2015 by the authors; licensee MDPI, Basel, Switzerland. This article is an open access article distributed under the terms and conditions of the Creative Commons Attribution license (http://creativecommons.org/licenses/by/4.0/). 